Journal of Sustainability Perspectives

\title{
Sustainable Universities _ The GreenMetric Tool As a Strategic Driver in HEls Considering Different Realities
}

\author{
Marinez Cristina Vitoreli ${ }^{1,}{ }^{*}$, Rodrigo Luiz Guarnetti ${ }^{2}$, Enzo Barbério Mariano ${ }^{3}$ \\ ${ }^{1}$ Centro Universitário ITE - Bauru, Brazil \\ ${ }^{2}$ Centro Universitário ITE - Botucatu, Brazil \\ ${ }^{3}$ Universidade Estadual Paulista Júlio de Mesquita Filho, Bauru, Brazil \\ *corresponding author: profamarinez@gmail.com
}

\section{Article Info}

\section{Received:}

15 March 2021

Accepted:

25 May 2021

Published:

1 June 2021

DOI:

https://doi.org/10.14710 /jsp.2021.11751

\begin{abstract}
In this work the considered concept of sustainability explores the relationships between economic development, environmental quality as well as social. Delineated by the UN in 1972, since then the subject has taken on great proportions, mainly due to its imminent urgency. In 2015 the theme was part of the UN's Sustainable Development Goals, making up the Agenda 2030. Recently, Higher Education Institutions have been compelled to offer their contributions, given their role in human formation. Considering GreenMetric's relevance since the beginning of its activities, its dimensions and indicators have offered relevant directions on the path of Sustainable Higher Education Institutions. Thus, the present work demonstrated, through the case study, how the dimensions and indicators proposed by GreenMetric could form part as an important strategic driver in the path of a Brazilian Higher Education Institution - Academic Center, located in the countryside of São Paulo State. Its registration at GreenMetric in 2019 allowed the same formulations of short, medium and long term strategies.
\end{abstract}

\section{Keyword:}

Higher Education Institutions; Sustainability; GreenMetric; Sustainable Development Goals.

\section{Introduction}

The concept of sustainability explores the relationships between economic development, environmental quality and social quality. Delineated by the United Nations (UN) at the United Nations Conference on the Human Environment, (Sweden, 1972). In the 1980s, the UN revived the debate and created the World Environment Commission, chaired by GroHarlenBrundtland, the then Prime Minister of Norway, taking a new look, defining it as the process that "meets present needs without compromising the ability of future generations to meet their own needs" [ 1 ]. In 2015, New York, new Sustainable Development Goals (SDS) were defined at the Sustainable Development Summit, culminating in the development of Agenda 2030, which has 17 SDS and 169 targets to be 
implemented globally by 2030 [ 2 ].

It should be noted that the concern with the state of the environment is not recent. In the last three decades of the twentieth century it has definitely entered the government agenda of many countries and various segments of civil and organized society [ 3 ], such as Higher Education Institutions (HEIs) that have made a significant commitment to sustainable action programmes in recent years. One of the most respected and adopted indexes has been GreenMetric created in 2010 at the University of Indonesia whose proposal is to adopt a sustainable development agenda [ 4 ]. Therefore, the general objective of this work is to address the issue of Sustainability in the context of Higher Education Institutions (HEls). As specific objectives, we intend to present the GreenMetric tool, which consists of a ranking where the classifications of the participating HEls are presented in the question of sustainable actions, pointing it as a strategic guideline in the context of a Higher Education Institution (Academic Center), located in the interior of the state of São Paulo, through a case study.

The research is mainly justified by the need to develop a better and deeper contextualization of the roles of HEls with respect to sustainable practices, both in the exercise of their role in the formation of ethical and responsible healers and also being a real example in their practices. It is hoped, through the case study presented, to create motivations so that other HEls can have a starting point for the adoption of sustainable practices as well as to show that it is possible to adopt such practices in a strategic way and without involving very high costs.

\section{Literature Review}

\subsection{Sustainability and Sustainable Development}

The theme of sustainable development has spread in the 21st century, and was represented as a theme and object of the Rio 92 discussions, which broke the paradigm of the infinity of resources, proposing that these resources be used in an appropriate and rational manner [ 5 ]. From then on, the three pillars of sustainability gain visibility (environmental, social and economic) by establishing guidelines for institutional tools such as the Sustainable Development Goals (SDG) and ISO 37120 (Sustainable Community Development: Indicators of municipal services and quality of life). SDGs are very important tools to guide this social and sustainable development globally, incorporating a shared and fair vision for all human beings [ 6 ]. The concept of sustainable development seeks to combine concerns about a variety of environmental issues with social and economic issues [ 7 ], [ 8 ].

\subsection{Importance of Indicators}

The term "indicator" is defined by several authors as a tool, measure or parameter. Indicator is all that one wants to measure, that is, it is the quantified representation of an information and generally not perceptible at a first moment, and it can have several purposes, according to the desired objective [ 9 ]. The advantage of using indicators is that it is easier to identify the main variables and synthesize and transmit information, used as a tool for identifying problems and making decisions, and the possibility of establishing standards and quantitative targets [ 10 ].

\subsection{The Ranking Green Metric}

GreenMetric is a ranking that presents the ranking of universities in terms of 
sustainable actions. Created in 2010 at the University of Indonesia with the intention of measuring the efforts of universities to practice sustainable actions. These Universities benefit from participating in this ranking because they gain international visibility, promote greater awareness of sustainability and interconnection with other Universities [ 4 ]. Overall, the ranking includes 5 categories: 1-Instructure, 2- Energy and Climate Change, 3- Waste (policies and treatments), 4- Water, 5-Transport and 6- Education. Each one with its respective weights, the highest scores being awarded to the Universities that meet the highest number of proposed requirements and their main objectives are to raise awareness about sustainability as well as to leverage the decisive role that HEls can play in the awareness and knowledge of this issue.

\subsection{Strategic Planning}

The Planning process is valid for any type of organization, being a public, private or non-governmental organization (NGO), also reaching the governmental spheres [ 11 ]. Complementing this, it is understood that "strategic planning is the establishment of a set of measures to be taken by the executive for a situation in which the future tends to be different from the past " [ 12 ], as well as strategic planning does not indicate how to manage day-to-day work, but shows how to structure actions, helping managers to organize their ideas and direct their actions [ 13 ]. Thus, sustainability issues are increasingly forming part of HEI strategic planning scopes, but there is still no golden rule when talking about good sustainable practices in HEls. The GreenMetric tool has been consolidated since its creation and is currently one of the main references in this matter.

\subsection{Methodological Approach}

The Toledo Institution of Education emerged as an educational project on April 21st, 1950, having as its main characteristic entrepreneurship and as a life mission to provide young Brazilians the opportunity to build their own future and their wealth, based on ethical values and social responsibility. Currently offers undergraduate courses in Law, Social Work, Administration, Economic Sciences, Accounting, Professional Steering, Aeronautical Sciences, Information Systems, Systems Analysis and Development and Production Engineering, in addition to Postgraduate Lato Sensu and Strictu Sensu. Throughout these 70 years dedicated to education, training ethical and responsible citizens, the institution has decided to embrace the cause of sustainability. Thus, in 2019 the institution was registered with GreenMetric. Being its first year of participation, knowing and answering the GreenMetric questionnaire provided great learning, as well as the survey of its strengths and weaknesses, in the field of sustainability. Thus, following the methodology of the proposed questionnaire, the data concerning the:

Dimension 1 - Infrastructure; Dimension 2 - Energy and Climate Change; Dimension 3 Garbage; Dimension 4 - Water. Indicators contemplating economy and recycling of water; Dimension 5 - Transport and Dimension 6 - Education and Research. After a brief analysis of GreenMetric's metrics system, the next session will present the main actions identified as important improvement points.

\subsection{Data Analysis}

After filling in the data with GreenMetric, the following points were raised in need of improvement, containing the status for each one.

1. Smart Building implementation - Status: Under analysis. $80 \%$ of lighting was already 
economical. Target: Increase the amount of other automated elements.

2. Number of renewable energy sources in campus - Status: We don't have. The viability of this issue is now being analyzed by the institution in the future.

3. Recycling program for University waste - Status: Implemented. In early 2020 separation dumps were installed throughout the campus, with an inauguration party as well as awareness-raising for administrative staff, faculty and students.

4. Program to reduce the use of paper and plastic in campus - Status: Implemented in early 2020 by placing signs on all copy machines and printers on campus. Awareness messages and tips for reducing the consumption of these materials by e-mail (to faculty) and students (via application).

5. Organic waste treatment - Status: in process. A compost plant will be installed between the end of 2020 and the beginning of 2021.

6. Inorganic waste treatment - Status: in process. Some opportunities for the reuse of discarded materials, such as electronic waste, have been identified by the innovation laboratory. Implementation between 2021 and 2022.

7. Sewerage disposal - Status: We don't have.

8. Water conservation program implementation - Status: We don't have.

9. Water recycling program implementation - Status: Under analysis. Feasibility analysis for the implementation of rainwater storage tanks.

10. The use of water efficient appliances - Status: Under analysis. Feasibility analysis for the implementation of rainwater storage tanks.

11. Total number of courses/modules offered - Status: Under analysis.

12. Number of scholarly publications on sustainability published - Status: Under analysis.

13. Under analysis.

14. Existence of a university-run sustainability website - Status: Implemented at the beginning of May 2020.

15. Training Programs: faculty, student and administrative - Status: enabled. Inauguration of programs via corporate e-mail (faculty) and application (students) with information and tips on sustainability and our program.

The road is known to be long, but the first steps have been taken. In this first year of registration we raised 15 possible points for improvement. Interesting to note that the items in the table listed with the numbers 3, 4, 14 and 15 were possible to be implemented almost immediately with the turn of the year $(2019-2020)$. This was because right after submitting the data to GreenMetric at the end of October 2019, these points were already raised, and it was found that, especially in these four dimensions, the costs for their implementation were practically zero. Thus, the dimensions and indicators of GreenMetric were considered of great importance as a driver of this first stage of implementation of improvements.

The items listed in 5 and 6 with the status "in process" are fully possible and achievable, but due to the suspension of classes because of the danger of contamination by COVID-19, their implementation has been postponed and is scheduled for late 2020 and early 2021.

As for items 1, 9, 10, 11, 12 and 13, which are "under analysis", these are also actions that are fully possible to be implemented but, as they involve somewhat higher costs and because of the OVID-19 pandemic, had their priorities changed for 2021 - 2022. Items 2, 7 and 8 do not yet have the necessary structure and know-how to make them viable, but they will remain on the agenda for future analyses since the institution wishes to expand its field 
of action in the sustainable sphere as well as to firm itself with the strategic positioning of differentiation and innovation.

\section{Summary/ Concluding Remarks}

The present work has analysed sustainability issues within the HEls, contextualizing them in the face of the major challenges present in this area in recent decades. The importance of a strategic planning of HEls in relation to the proposed challenges was highlighted, as well as the analysis of the GreenMetric tool as a strategic guideline towards more sustainable actions in HEls. The main contributions of the work were the experiences of a Brazilian Academic Centre, located in the countryside of Brazil, which until now, unaware of GreenMetric's indicators but motivated to improve its environmental and sustainable practices, has registered participation as well as demonstrated that it is possible to improve its indicators and, in the case presented, with relatively low costs.

Concern about cost generation is part of any strategic planning, often such cost estimates can simply make a plan unfeasible. Thus, it was intended to demonstrate that, when it comes to sustainability, some important actions are possible to implement, at low cost, depending only on goodwill, dedication, focus and commitment to the cause.

\section{References}

1. RDM. Relatório sobre o Desenvolvimento Mundial de2010 - Visão Geral - da mudança do clima para o densenvolvimento. Washington: Banco Internacional de Reconstrução e Desenvolvimento / Banco Mundial, 2010. Available at: http://siteresources.worldbank.org/INTWDR2010/Resources/5287678226014527953/WDR10 AdOverview BP Web.pdf. Access in 4 abr. 2019.

2. ONU-BR. Transformando Nosso Mundo: A Agenda 2030 para o Desenvolvimento Sustentável. Nações Unidas no Brasil, 2017. Available at:.<https://nacoesunidas.org/pos2015/agenda2030/> Access in: 21 out. 2019.

3. BARBIERI, J. C. Gestão Ambiental Empresarial. São Paulo, Atlas, 2014.

4. UI GREENMETRIC. 2019. Available at: <http://greenmetric.ui.ac.id/overall-ranking2019/>. Access in: 08 ago. 2019.

5. LEITE, C. AWAD, J.C.M. Cidades Sustentáveis, Cidades Inteligentes: desenvolvimento Sustentável Num Planeta Urbano, Bookman, Porto Alegre, p. 264, 2012.

6. LEAL FILHO, W., TRIPATHI, S.K., ANDRADE GUERRA, J.B.S.O.D., GINÉ-GARRIGA, R., LOVREN, V.O., WILLATS, J. Using the sustainable development goals towards a better understanding of sustainability challenges, International Journal of Sustainable Development and World Ecology, 2018.

7. MEADOWS, D., MEADOWS, D. RANDERS, J., Beyond the Limits: Global Collapse or a Sustainable Future, Earthscan, London, 1992.

8. SNEDDON, C., HOWARTHB, R.B. AND NORGAARDC, R.B., Sustainable development in a post-Brundtland world, Ecological Economics, v. 57, n. 2, p. 253-268, 2006.

9. OLIVEIRA, M.; LANTELME, E.M.V.; FORMOSO, C.T. Sistema de indicadores de qualidade e produtividade na construção civil: manual de utilização. SEBRAE, Porto Alegre, 1995.

10. DGA. Proposta para um Sistema de Indicadores de Desenvolvimento Sustentável. Portugal, Direç̧ão Geral do Ambiente, 2000. Available at: $<$ https://apambiente.pt/ zdata/Divulgacao/Publicacoes/SIDS/SIDSPortugal Proposta200 0.pdf.> Access in: 01 out. 2019.

11. PEREIRA, M. F. Planejamento Estratégico: teorias, modelos e processos. São Paulo, 
Atlas, 2010.

12. OLIVEIRA, D. P. R., Planejamento Estratégico: conceitos, metodologias e práticas, 25 ed. São Paulo: Atlas, 2008.

13. ALMEIDA, M. I. R de, Manual de Planejamento Estratégico: desenvolvimento de umplanejamento estratégico com a utilização de planilhas Excell. 3 ed. São Paulo: Atlas, 2010. 